\title{
The Joint Accounting/e-Business Technology Major: An Inter-disciplinary Approach To Curriculum Development
}

\author{
Vince Brenner \\ Ted Surynt \\ Fred Augustine \\ vbrenner@stetson.edu \\ tsurynt@stetson.edu \\ faugusti@stetson.edu

\section{Stetson University, DeLand, FL, USA}

Judson Stryker

IStryker@stetson.edu

\begin{abstract}
The promise and potential of the new business paradigm labeled "e-business" is the driving force behind the tremendous demand for accounting professionals with both a technology background and a traditional accounting background. Where will these professionals come from? This paper lays out in detail the foundation for a new undergraduate academic program which is designed to both attract students and to provide them with the skill set necessary to succeed in this new e-business universe - the Joint Accounting/e-Business Technology major. Course content for this undergraduate major is based on a set of courses designed to integrate concepts and technologies necessary for an understanding of the infrastructure that supports e-business. Students, recruiters, and faculty will appreciate the distinct competitive advantages offered by this unique program.
\end{abstract}

Keywords: Accounting, Electronic-Business, Technology, Undergraduate, Curriculum

\section{Introduction}

It should come as no surprise to any accounting or business systems professional that Accounting as a profession is undergoing a not-so-quiet revolution. The catalysts for this dramatic change are found in the recent advancements in computer technology and the advent of e-business. While these changes have been taking place in the practice community for years, they have been accelerated by the advent of the new e-business model and the integrative discipline of ERP systems. Consulting Services, primarily involving technology, have grown to be the largest part of an accounting firm's practice and in some notable cases have been spun off to become separate consulting firms.

Even in the traditional accounting practice areas, new techniques and approaches are used to audit ebusiness clients and ERP systems. Internal control assessment now requires new innovative methods [Tucker 2001]. Staff accountants routinely link to centralized client databases via laptops. The e-business model is significantly changing both the way business is done and the accounting and auditing of those businesses.

Not surprisingly, the AICPA and NASBA have realized that the CPA exam needs to change in order to more properly reflect the evolving nature of accounting practice. They have performed an extensive practice analysis to determine the basic skills needed by new CPAs and are changing the content of the exam

Material published as part of these proceedings, either on-line or in print, is copyrighted by Informing Science. Permission to make digital or paper copy of part or all of these works for personal or classroom use is granted without fee provided that the copies are not made or distributed for profit or commercial advantage AND that copies 1) bear this notice in full and 2) give the full citation on the first page. It is permissible to abstract these works so long as credit is given. To copy in all other cases or to republish or to post on a server or to redistribute to lists requires specific permission from the publisher at Publister@intormingscience.org based on this analysis. The exam content will include more in the technology area. Even the approach to the exam itself is being changed to reflect current practice. It is expected that the exam will be a computerized exam by 2003 and will require the use of the computer and the Internet to solve exam problems [Holder and Mills 2001]. 
While technology changes have made accounting practice more technology oriented and more exciting, the number of students coming into the profession continues to decline. The number of students entering systems and technology programs however continues to increase. Many in the current practice community believe the decline in accounting enrollments can be attributed, at least in part, to a lack of awareness by students of the current nature of accounting practice [Albrecht and Sack 2000, 28]. Accountants are much more involved in technology and are acting more as business advisors rather than simply business reporters.

Another factor contributing to the decline in accounting enrollments is the 150-hour requirement, in most states, to sit for the CPA exam [Albrecht and Sack 2000, 30]. Many students do not see the incremental pay and opportunities as being worth the time and expense of an additional year of education. This opportunity cost is particularly evident when comparing a career in accounting to careers in information systems.

\section{Technology Issues Facing the Profession}

The AICPA technology committees have identified the 10 most important technological challenges and opportunities facing professional accountants [Tie 2000].

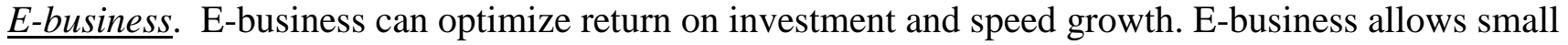
companies to compete with the largest companies and creates new opportunities for all businesses. To effectively advise clients, accountants need to know the e-business culture, its benefits and problems.

Information security and controls. There will be continued and increased security threats as more systems are moved online. This historically has been an area of accountant expertise. Current technology advances, however go well beyond traditional capabilities and accountants need significantly more technical background if they are to be effective in the future.

Training and technology competency. Accountants must have technology training that focuses on developing skills to assist clients with their goals. Lifetime learning programs are essential for highly skilled professionals and time for training is always a problem. Having fundamental technological skills entering the profession can enhance career progress.

Disaster recovery. It is a subject that is frequently discussed, but in light of recent terrorist attacks awareness will be heightened for this pressing need.

High availability and resiliency of systems. It is essential that systems are available when clients need them. Timeliness and flexibility in gathering and reporting financial information will be expected in the future.

Technology management and budgeting. Business process outsourcing (BPO) is expected to explode, as many high growth firms want to focus on their core competencies. CPAs as well as other accountants will find a high demand for these services if they have the necessary systems competence.

Electronic financial reporting. The AICPA's XFRML project has provided better tools and processes to create these reports but there are significant issues related to required compilations. New, creative ideas in advanced technologies can resolve these problems.

Internet Issues. Because nearly half of the American population will use the internet, the accounting profession must have the skills and the expertise to take advantage of this vast market.

Virtual Office. The accountant must have an exceptional work ethic to succeed in this new environment. It will be essential to have special technical training that will allow the accountant to be more selfsufficient and independent. 
Privacy. With the growth of e-commerce, the internet and new web technologies, privacy becomes a major concern for many clients. How the accountant deals with sensitive data transfers will require substantial technical expertise in the future.

The bottom line is that the limited technology background of the traditional accounting graduate will not allow them to effectively assist firms and their clients in addressing these priority issues.

\section{Needed Changes in the Accounting Curriculum}

The passed two decades of change requires an accountant entering the profession to possess a different skill set than the accountant of the 1980's and 1990's. The accounting graduate must still possess strong analytical and problem solving skills, be articulate with effective communication skills, and have the traditional accounting, audit and tax skills. But to be competitive in today's market, the aspiring accountant must also be well grounded in business systems and e-business technology.

On the other hand, since the economy began shaking out those marginal "dot-com" firms with inoperable business models, a wave of experienced "systems" professionals found themselves on the street. Many trade publications proclaimed that, virtually overnight, the sellers market of systems people became a buyers market of companies looking to hire them. What is not often discussed, however, is that much of this glut of available technology professionals consists of people with very specific technology skill sets and not much in the way of business acumen. A case can still be made that the shortage of business savvy and technology savvy professionals remains unabated. Arguably, the factor that contributes most to this demand is the continuing movement toward electronic business processes and their strategic impact. Industries and individual companies continue to see the value of e-business and are moving forward on numerous fronts. If nothing else, the demise of the dot-coms signaled the end of the "wild west" phase and the beginning of a more mature, planned progression to e-business. As before, the technology expertise required to support e-business will continue to place ever-greater demands on our pool of IT professionals. As the accounting profession shifts to accommodate the changing requirements of the evolving ebusiness model, individuals with a strong technical background and an innovative accounting skill set will undoubtedly be in high demand.

The traditional accounting program required one basic information technology course (introduction to various types of software such as word processing, spreadsheets, etc.) followed by an accounting systems course. Today's accounting professional is in need of more extensive training in ERP systems, e-business technology, information security and controls, etc.

\section{The Need for a New Major}

There is a definite need for individuals with both a strong accounting and information systems background. Today's typical accounting graduates have an insufficient technology background to even audit today's complex information systems, let alone the ability to assist clients in assessing system requirements, system selection and implementation, or the tailoring of these systems to fit a client's specific needs. On the other hand, an e-business technology graduate possesses knowledge of a system's technological capabilities but is not well versed in accounting information systems, design of accounting reports needed by management, information security, internal controls, etc.

A new major is needed that will focus on accounting principles and methods, accounting information systems, and e-business technology. Such a major would be a four-year program designed for students not planning to enter public accounting. These students would be trained in financial accounting and reporting, cost and managerial accounting and accounting information systems. They would get the traditional problem solving and analytical skills involved in accounting programs as well as research skills using the web and other electronic media. 
In the technology area, the students would need not only a minimal exposure to a programming language, but also intensive courses in e-business technologies, ERP systems and databases.

Students enrolled in this new major who desire a career in public accounting would have to take an additional year of study in order to qualify to sit for the CPA exam. Course work in this fifth year would involve the more traditional accounting areas such as audit and tax.

\section{Program Philosophy}

One career advantage that students graduating from a school of business with a traditional technology (IS, MIS, CIS) degree have always had is an exposure to a broad spectrum of business concepts. Accounting programs traditionally have been the bedrock of the business school, providing students with skill sets crucial to the function of the enterprise. The key issue for combined programs of the future is how to effectively build on this business foundation to produce graduates with the technical skills desired by recruiters. A typical business technology graduate has strong technical skills in computers and systems but generally a weak background in accounting or accounting information systems. Most technology consultants do not have an accounting background and cannot therefore adequately relate to issues and problems involved in accounting information systems. This program will provide a graduate who is trained in both technology and accounting. This rather rare combination will be in high demand by both consulting firms and corporate America. Students who choose to continue their education to qualify to sit for the CPA exam will also be very appealing potential employees for traditional CPA firms. They will have a skill set not found in the traditional accounting student.

The following section addresses four key areas in the development of a new program.

Targeted students: Students recruited for this program will not be traditional accounting students. This major will appeal to students who have a strong interest in technology and e-business but who are also interested in understanding the accounting principles which underscore e-business success. Students will appreciate the uniqueness of the combined program and the career growth and security that it offers. In all probability, most students seeking this path will not move into traditional public accounting positions because their technology background will afford them the opportunity to enjoy high paying and challenging careers without the necessity of a fifth year of study.

Targeted employers: It is anticipated that these students will be seeking careers more with consulting firms such as Accenture and Booze Allen, or consulting staffs of CPA firms. Graduates will also be recruited by corporations with accounting information systems and e-business staffs.

Accounting focus of major: The new major will support the traditional areas of financial accounting and reporting, financial statement analysis, and managerial and cost accounting systems. There will be much more emphasis on accounting information systems and controls, systems analysis and design, management of technology, electronic reporting, and ERP systems. An essential element will be practical experience through an internship in a systems environment such as ERP.

E-business technology (EBT) focus of major: The EBT focus of the major ensures that the students will have the technical/systems background to apply their accounting skills in an innovative "e-business manner". Students will be exposed to programming basics and will study e- commerce and related issues and technologies, data base design and development, and ERP systems.

\section{Course Roadmap}

The program will consist of the following accounting and e-business technology courses, in addition to the introductory accounting and technology courses. Note that credit hours designated for each course are semester hours. 


\section{Accounting Courses}

Financial Accounting (6 hours): These are the traditional intermediate I and II courses involving financial accounting and reporting. In addition to the traditional topics, students will be introduced to ERP systems and will work exercises with the SAP system. Students will also be given cases that will require research and written reports as well as presentations of case and analytical problems, to further develop communication and presentation skills.

Cost/Managerial Accounting ( 3 hours): This will include the typical topics covered in such a course, e.g. cost behavior, activity based costing, budgeting and planning, responsibility reporting and performance measurement, etc. The course will also use the SAP controls module to illustrate a cost accounting system and extract information for analysis and internal reporting.

Accounting Information Systems I (3 hours): This course is intended to serve as an initial required course in the accounting information systems track as well as a required overview course for other accounting majors. It will examine contemporary topics concerning the use of information technology and accounting information systems by modern business organizations and to explore the accountant's potential role as user, manager, auditor, and/or designer of such technologies and systems. Topics include: systems description and documentation, transaction processing and primary transaction cycles, database management systems, electronic business/commerce systems, accounting systems software, enterprise resource planning systems with particular emphasis on SAP applications, internal control and IT security, and the systems development process. Emphasis will be placed on oral and written communications skills, research skills, critical thinking, and hands-on practical real-world application. The latter item requires groups of students to describe and flow chart a transaction cycle for a real business and analyze its strengths and weaknesses. Both written and oral reports will be made on the project.

Accounting Information Systems II (3 hours): This course is intended to serve as a subsequent required course in accounting information systems; accounting majors will not be permitted to take this course. It will be designed to explore, in some depth, the principle vulnerabilities of and threats to information technology and accounting information systems. It will also examine, in detail, the corresponding security and internal controls necessary to protect organizational IT and AIS resources and reduce risks associated with such technologies and systems. Topics include: non-subversive/unintentional threats, subver-

sive/intentional threats, computer-based information system and technology exposures and vulnerabilities, computer and network security fundamentals, pervasive controls/countermeasures (e.g., operating system controls, data management and database controls, organizational structure controls, systems development controls, systems maintenance controls, computer center security and controls, network and e-commerce controls, and personal computer controls), and application controls/countermeasures (e.g., input controls, processing controls, and output controls) for primary transaction cycles.

AIS Internship (3 hours): The intent is to have this internship in an SAP environment with a consulting firm or corporation.

\section{E-Business Technology Courses}

Java Programming for the Web (3 hours): This course focuses on programming of web-based applications. As the course title states, Java will be used as a first programming language. The assumption is that the student has no prior programming experience. Although our current programming toolbox consists of a visual, rapid application development environment, the course does not concentrate on development tools, per se. Focus is on programming concepts and structures. Principles of programming style are emphasized. Classes, constructors, and keywords are stressed along with an introduction to applets and applications. The programming experience gained in this class should be transferable to any $3^{\text {rd }}$ generation 
or object-oriented programming language. Students should come away from this course with a thorough grounding in how to problem-solve using programming as the solution mechanism.

Electronic Commerce (3 hours): This course provides an in-depth examination of the concept and application of electronic commerce. It is one of the "soft" technology courses within the major. Some hands on work is done through the use of SAP R/3 in an effort to introduce the students to business process integration. E-commerce topics are explored in detail using both lecture and case methods. Topics include an overview of the critical information technologies that provide a basis for electronic commerce, ecommerce business models, the effect of Internet commerce on existing business models, and important issues surrounding the implementation of e-commerce in organizations. Students completing this course have a good foundation in the strategic issues, which affect the e-commerce subset of e-business.

E-Business Communication Networks ( 3 hours): This course provides an in-depth examination of data communication processes and structure. Central focus is on LAN, WAN, and Intranet technologies, as well as design and implementation of networking applications within the organization. Although it focuses primarily on networking support of web-based communications, it necessarily must deal with LAN's, NOS's, and hardware concepts. Both Linux and Windows networking are discussed as well as Novell's Netware. Network concepts, e.g. structure, topologies, protocols, and administration, are presented in detail. Hands-on work includes not only network design, but also actual installation, including hardware (cables, switches, etc.) and software components. Students take away from this class the ability to design, build, and administer the networks which support e-business.

E-Business Database Development (3 hours): This course provides in-depth coverage of database technology issues including data modeling, CASE, logical design, and implementation in a relational DBMS environment. Students gain hands-on experience in the use of enterprise-level development tools. There are three technical objectives to this class, all based on the assumption that RDBMS's will remain the database engine of choice for the foreseeable future. Since relational tables will continue to provide the back-end storage component of web-based systems, students are given an extensive exposure to table design. SQL is then presented in detail. Finally, utilizing Java, SQL, and other tools, the students put together the back-end components of a production quality e-commerce web site. MS SQL Server is the database of choice for this class due to its relative ease of administration, and the fact that students have had extensive exposure to MS Access in earlier business foundation classes. Students finish this course with the background necessary to both design and program the database support necessary to maintain ebusiness systems.

Enterprise Systems Management (3 hours): This course provides an extensive investigation into the business environment of enterprise resource planning systems. Discussion topics include competition in the ERP arena, ERP architectures, evaluating and modeling business processes, and implications for ebusiness. Case studies will be used to explore the management issues of effective use of information technology within the organization. This course is designed to give the students a detailed look at enterprise back-end systems and processes, as well as the new web-based initiatives (portals, B2B, CRM, etc.) from the traditional ERP vendors. Although very much a case-based course, the students will also have significant hands-on exposure to SAP. The student should take away from this course a thorough understanding of business process integration, as well as a feel for how traditional ERP systems are being re-defined and re-cast around web technologies.

\section{Challenges}

The described program faces many challenges some of which are addressed below:

Accreditation Issues: While there have been calls for drastically changing accounting programs [Albrect and Sack 2000] there is uncertainty as to how the AACSB will view such changes when considering ac- 
creditation. AACSB encourages the development of broad and diverse programs in accounting. The standards for separate accounting accreditation indicate that a minimum of 21 hours are needed in accounting, including six hours of introductory accounting. It would appear that the program would meet these standards. However, it must be remembered that the accreditation process is mission driven and it would be necessary for schools to adjust their mission to include a joint program of this type.

Faculty issues: The described program will require faculty members sufficiently trained in information technology to teach the accounting systems courses. Given the shortage of faculty in this area and the high salaries, such a program may be beyond the reach of many schools. Faculty in financial and cost accounting will also need a background in SAP, or other selected ERP software, if it is to be implemented in these courses. This will most likely mean required attendance at software training courses. The increased technology will also increase the need for continuing education because of the rapidly changing nature of information technology. Both of these increase costs for the institution in terms of travel, faculty released time, conference fees, support grants, etc. It may also be necessary to provide incentives for faculty to get them involved in such a program. Significant additional time will be needed to prepare for classes and this will take away from other faculty efforts such as research and service. Encouragement can be provided through released time, summer support grants etc. The University administration must recognize these efforts and their potential impact on research or service productivity.

Attracting Students: For the program to be viable it must attract a critical mass of students. This may not occur in the first year or two because of student uncertainty concerning the desirability of such an undergraduate degree. The university needs to be committed to the start up time and realize that it may take a year or two to attract a desirable quantity of students. For the program to be successful the students need to be those with excellent academic credentials. For this reason, the program may have higher GPA standards than other programs. This will create a unique academic major that will be attractive to both students and potential employers. Meaningful, well paying summer internships will also help attract students. The most effective way to attract top quality students will be the placement of graduates in high paying positions.

Attracting employers and internship opportunities: The joint major provides a unique individual to the market. Employers are looking for technically competent students who have both interpersonal and communication skills. It is important to have potential employers involved in the program before interns or graduates are to be placed. Employers can provide speakers for classes, field trips, etc. It is preferable to have upper level management in accounting systems involved in the process because they are the individuals who can most directly affect internships and employment. Making these individuals aware, on a first hand basis, of the program and the quality of students in the program is the most effective approach in student placement. Providing internships will also give potential employers a chance to observe students in the work environment before full-time employment offers are extended.

\section{Conclusion}

Application of technology in the business environment continues to change rapidly. The accounting professional of the future must have more e-business technology education if they are to be successful. This is evidenced by calls from both educators and accounting professionals for changes in the curriculum. It is also evidence by proposed changes in the CPA exam and the AICPAs project to expand services offered by CPAs. The joint program outlined above meets these new challenges and will provide graduates who are unique to the market place. They will be professionals who are competent in both accounting and ebusiness technology.

Most academic institutions have experienced declining enrollment in accounting, a traditionally high enrollment area. The described program will attract new and better students and will reverse the current 
trend in accounting education. While the initial investment for the university may be significant, the long term benefits to the university, students, and the business community are even greater.

\section{References}

Albrecht, Steve W. and Sack, Robert J. (2000). Accounting Education: Charting the Course through a Perilous Future, Sarasota, FL. American Accounting association.

Holder, William W., and Mills, Craig N. (March 2000). Pencils Down, Computers Up -The New CPA Exam, The Journal of Accountancy, pp. 57-60.

Tie, Robert. (2000 March). E-business Tops Tech Priorities for CPAs. The Journal of Accountancy, pp.20-21.

Tucker, George H. (2001 September). IT and the Audit, The Journal of Accountancy, pp. 41-43.

\section{Biographies}

Vincent C. Brenner, Ph.D., CPA is Chairman and Beights Professor of Accounting at Stetson University. He is the author of two textbooks, has published over fifty papers in a variety of academic and professional journals such as The Journal of Accounting Research, The Accounting Review, and The Journal of Accountancy. He has been active at the national level in organizations such as the AICPA, the Institute of Internal Auditors and the American Accounting Association. In 1991, he received the international educator of the year award from the Institute of Internal Auditors. He has received numerous awards for teaching, research and service.

Theodore J. Surynt, Ph.D. (Georgia State University) is Professor of Information Systems and Associate Dean of the Stetson University School of Business Administration. During his nineteen years at Stetson, he has been instrumental in the creation of business technology programs at both the undergraduate and graduate level. He has published numerous articles dealing with Information Systems pedagogical issues. He is owner and president of Surynt Computer Services, a software consulting and contract-programming firm. Prior to coming to Stetson, he was a Systems Engineer and Corporate Planning Analyst for IBM Corporation.

Judson P. Stryker, Ph.D., CPA has been a member of the Stetson University accounting faculty for twenty-five years and has been actively involved in curriculum revisions during his tenure. While serving as Associate Dean, he chaired the successful AACSB accreditation of Stetson's Business School and understands the necessary accreditation curriculum requirements. Dr. Stryker has also served as Vice President of Finance for Stetson and has been involved in curriculum issues at the University level. He received his doctorate from Mississippi State University and is a licensed CPA in the state of Florida where he has had an accounting and consulting practice for twenty-seven years. Prior to joining Stetson, Dr. Stryker taught at Embry Riddle Aeronautical University for two years and served in various supervisory and management positions with the General Electric Company for eleven years.

Fred K. Augustine, Jr., Ph.D. (Florida State University) is Associate Professor of Information Systems at Stetson University. He has written articles published in the Journal of Systems Management, The Journal of Computer Information Systems, System Dynamics Review, Journal of End-User Computing, CIS Educators Forum, Interface, E-Business Review, and others. His primary research interests are in the areas of the organizational issues involved in the use of web technologies and the issues involved in the development and implementation of e-Business systems. 